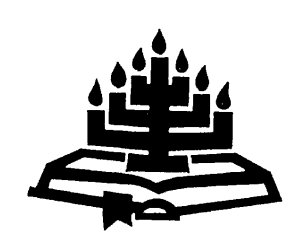

\title{
Die pneumatologiese lied: basisteoretiese perspektiewe (uit Romeine 8:1-27) en empiriese gegewens
}

\author{
B.J. de Klerk
}

Skool vir Kerkwetenskappe

Potchefstroomkampus

Noordwes-Universiteit

POTCHEFSTROOM

E-pos: kwsbjdk@puknet.puk.ac.za

\begin{abstract}
Pneumatological hymns: Basis-theoretical perspectives (according to Romans 8:1-21) and empirical facts

In this article Romans 8:1-27 is investigated in order to trace basis-theoretical perspectives on pneumatological hymns and to determine empirically the scope and nature of pneumatological hymns in Psalmboek, Liedboek van die Kerk and Psalter Hymnal. The basis-theoretical investigation reveals that there is a pressing need for appropriate Scriptural hymns on the Person and work of the Holy Spirit. Characteristics and functions of the Spirit that are essential to the church and her creeds are not found in current versifications of certain parts of Scripture. New hymns on the Person and work of the Spirit can preserve and breathe new life into creeds on the Holy Spirit, protect the congregation against fallacies and touch the hearts of doubters and unbelievers in a unique way. From the empirical facts an idea is formed of the state of affairs regarding the hymnology on the Person and work of the Holy Spirit. An investigation into themes on the Person and work of the Spirit not present in current Scriptural hymns also leads to the conclusion that there is scope for new Scriptural hymns.
\end{abstract}

\section{Opsomming}

Die pneumatologiese lied: basisteoretiese perspektiewe (uit Romeine 8:1-27) en empiriese gegewens

In hierdie artikel word Romeine 8:1-27 ondersoek om basisteoretiese perspektiewe op die pneumatologiese lied te identifiseer en om die omvang en aard van die pneuma- 
tologiese lied in die Psalmboek, Liedboek van die Kerk en die Psalter Hymnal empiries te bepaal. Uit die basisteoretiese ondersoek blyk dat daar 'n dringende behoefte is aan toepaslike Skrifberymings oor die Persoon en werk van die Heilige Gees. Eienskappe en funksies van die Gees wat van deurslaggewende belang vir die kerk en sy belydenis is, kom nie in die huidige berymings van Skrifgedeeltes voor nie. Nuwe liedere oor die Persoon en werk van die Gees kan die belydenis oor die Gees bewaar en nuwe lewe inblaas, die gemeente teen dwaling beskerm en die belydenis op 'n unieke wyse in die harte van twyfelaars en ongelowiges indra. Met behulp van die empiriese gegewens word 'n beeld gevorm oor die stand van die liedereskat oor die Persoon en werk van die Heilige Gees. Uit 'n ondersoek na verskeie temas oor die Persoon en werk van die Gees wat nié in die huidige Skrifberymings voorkom nie, word afgelei dat daar ruimte is vir nuwe Skrifberymings.

\section{Inleiding}

Liturgiese sang is gerig op die God van die openbaring en sy openbaring is die grond en oorsaak van enige himniese aktiwiteit. Liturgiese sang is egter meer: dit impliseer openbaring in responsiewe aksie, want openbaring word geaktualiseer in sang. Die aktualisering van die openbaring word ook die artikulering van die openbaring in die belydenis van geloof (Bingle, 2000:34). Indien 'n bepaalde openbaringswaarheid in die huidige gelowiges se bestaanswêreld in gedrang kom, behoort dit ook liedmatig beantwoord te word. Dalk is die Persoon en werk van die Heilige Gees in die lied onderbeklemtoon in reaksie teen 'n soort geesdrywery en daarom behoort so 'n openbaringswaarheid wat onwillekeurig onderspeel word, liedmatig geaktualiseer en reggestel te word. Soos ander liturgiese handelinge, byvoorbeeld die prediking, die hele Raad van God moet verkondig, moet die repertoire van die kerk se liedereskat dit ook doen, want die teologie van die gemeente kom ook tot uitdrukking in sy liedere (Shelt, 1996:71). Al is die Skriflesing, prediking en belydenis van die gemeente 'n bevestiging van die leer van die kerk, is dit die woorde van die lied wat die hart van die lidmate vul in tye van krisis en wanneer hulle leiding soek in noodsituasies (Malan, 1998:522).

Die vervul wees met die Heilige Gees het as uitvloeisel dat die gemeente onder mekaar psalms, lofgesange en geestelike liedere sing, dat hulle sing met hulle hele hart tot eer van God (Ef. 5:18, 19). Dan moet die gemeente ook sing oor die Persoon en werk van God die Heilige Gees, want die gemeente leef nou in die laaste dae, die aeon (bedeling) van die Heilige Gees. Die sangers betree dus 'n 
nuwe geloofswerklikheid en die lied moet die krag besit om hierdie geloofswerklikheid vir die deelnemers in die liturgie te open (Bingle, 2000:157). Die Vroeë Kerk het nuwe liedere oor Christus saamgestel onder die leiding van die Heilige Gees (vgl. Fil. 2:5-11; Kol. 1:15-20 en verskeie liedere in Openbaring; Malan, 1998:512).

Is daar in gereformeerde kerke genoegsame en doeltreffende berymings van Skrifgedeeltes wat oor die Persoon en werk van die Heilige Gees handel? Om 'n antwoord hierop te probeer verkry, sal die volgende metode en werkplan in die artikel gevolg word: Eerstens sal gepoog word om eksegeties, volgens gereformeerde hermeneutiese uitgangspunte (vgl. De Klerk \& Janse van Rensburg, 1999), basisteoretiese perspektiewe vir die pneumatologiese lied uit Romeine 8 vas te stel. Tweedens sal 'n empiriese ondersoek die omvang en inhoud van pneumatologiese liedere in die Psalmboek (PB), die Liedboek van die Kerk (LB) en die Psalter Hymnal (PH) probeer bepaal. Samevattende gevolgtrekkings sal gemaak en enkele moontlikhede vir die beryming van nuwe pneumatologiese liedere uit gedeeltes van die Nuwe Testament sal aangedui word.

\section{Basisteoretiese perspektiewe vir die pneumatologiese lied uit Romeine 8}

Liturgiese sang in die Nuwe Testament impliseer benewens die element van aanbidding waarin God verheerlik word, 'n handeling van die geloofsgemeenskap wat berus op die openbaring van en deur God (Bingle, 2000:8). Die tipiese aard van die openbaring roep by die hoorders 'n antwoord op. Hierdie antwoord kan wees in die vorm van verkondiging, belydenis, skuldbelydenis, nuwe verbintenis aan God, ensovoorts. Die antwoord op die openbaring, van watter aard dit ook al mag wees, kan in liedvorm uitgedruk word. Daarom is dit nie noodwendig net Nuwe-Testamentiese liedere wat in liedvorm omgedig kan word nie, maar ook ander gedeeltes waarin God Hom openbaar. Die openbaring van die Heilige Gees in Paulus se prediking deursuur al sy briewe, maar ten minste vier dele is van kardinale belang hiervoor:

- Galasiërs 5 (die vrug van die Gees in die lewe van die gelowige);

- 1 Korintiërs 12-14 (die werk van die Gees in die opbou van die kerk as liggaam van Christus);

- 2 Korintiërs 3 (die verhouding Heilige Gees en nuwe eeu en die verhouding Heilige Gees en Christus) en

- Romeine 8 (Coetzee, 1984:234). 
Coetzee (1984:234) sê Romeine 8 handel oor byna die hele linie van die openbaring van die Heilige Gees. Romeine 8 word genoem die hoofstuk oor die Heilige Gees (Lambrecht, 1992:94). In Romeine 1-7 kom die begrip $\pi \nu \in \hat{v} \mu \alpha$ net vyf keer en van Hoofstukke 9-16 net agt keer voor, en in Hoofstuk 8 ten minste 21 keer (Moores, 1995:111).

Dit word algemeen ervaar dat die tema van Romeine in Hoofstuk 1:16, 17 aangedui word en so saamgevat kan word: Die mens wat onskuldig verklaar is (regverdig is) deur die geloof, sal lewe. Die brief is in die vorm van 'n hofsaak geskryf met 'n klagstaat (1:18$3: 20)$, 'n uitspraak (3:21-4:25), 'n vonnis (5:1-11:36, met hoofstukke 9-11 wat Israel as voorbeeld van regverdigmaking deur die geloof voorhou) en die lewenswandel na die uitspraak en vonnis (12:116:27; vgl. Coetzee, 1986:10-12). Die deel waarin Romeine 8 voorkom, word soos volg verdeel:

- Die nuwe lewe - bevry van die toorn van God (Hoofstuk 5)

- Die nuwe lewe - bevry van die sondemag (Hoofstuk 6)

- Die nuwe lewe - bevry van die wet (Hoofstuk 7)

- Die nuwe lewe - bevry van die dood deur die lewendmakende Gees (Hoofstuk 8:1-30)

- Die oorwinningslied van die verlostes (Hoofstuk 8:31-39).

Dit word taamlik algemeen aanvaar dat Romeine 8 verdeel kan word op die volgende wyse: Vers 1 as opskrif; verse 2-17; 18-30 en 31-39 (vgl. Van Rensburg, 1982:161). Die groter dele kan ook in eenhede rondom die volgende tema ingedeel word: Persoon en werk van die Heilige Gees. Dan sou die tema en indeling van hoofstuk 8:1-39 soos volg kon uitsien:

Die nuwe lewe - bevry van die dood deur die lewendmakende Gees

- Beheers deur die Gees (8:1-8)

- Lewe deur die Gees (8:9-11)

- Kinders van God deur die Gees (8:12-17)

- Hoop deur die Gees (8:18-25)

- Bid deur die Gees (8:26-27).

Alles is volgens God se verlossingsplan (8:28-30) en daarom is daar volkome sekerheid van verlossing (8:31-39). 


\subsection{Beheers deur die Gees (Rom. 8:1-8)}

Paulus het reeds in Romeine 7:6 oor die nuwe lewe deur die Gees geskryf en nou sluit hy daarby aan. Die grondstelling in Hoofstuk 8

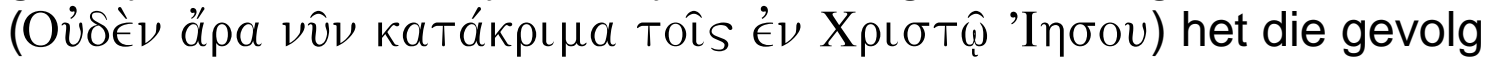
dat die gelowige vrygestel is van die heerskappy van die sondige natuur, wat niks anders as die dood is en nou onder heerskappy van die Gees gestel is. Die nuwe mag wat saam met Christus na vore

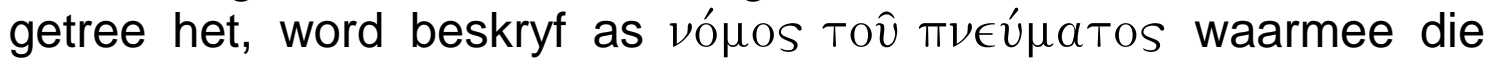
beheersing deur die Gees aangedui word. Die Gees wat lewe skenk, is die Gees van Christus en daarom bring Hy vryheid, innerlike en geestelike bevryding van die mag van die sonde. Noudat die Heilige Gees die gelowiges uit die geestelike dood lewend gemaak en in Christus ingeplant het, leef hulle in 'n nuwe orde of bedeling, onder beheersing van die Heilige Gees (Wedderburn, 1991:135). Die eenheid van die opgestane Christus en die Gees lê in dieselfde lewe wat Christus deur sy opstanding verwerf het en deur die Gees aan die gelowiges geskenk het (Versteeg, 1971:348).

Dit is dus duidelik dat die groot teenstelling in hierdie verse tussen die sondige natuur en die Gees is. Dié wat deur die Gees beheers word, fokus op die dinge van die Gees. Dit gaan dus oor die mag wat die Gees het oor diegene wat Hy beheers: Hy beheers hulle handelinge en bepaal die bestaan van die gelowiges. Die sondige natuur rig hom op dit wat vyandskap teen God impliseer. Diegene wat in vyandskap teen God leef, word beheers deur 'n vyandige en opstandige mag teen God. In hierdie lewensfeer kan die mens geen lewe verwag nie. Diegene wat deur die Gees beheers word, leef in die lewensfeer van die Gees wat gekenmerk word deur $\zeta \omega \grave{\eta}$

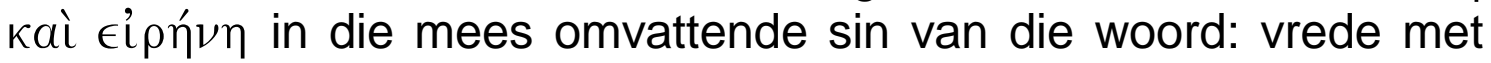
God en vrede onderling (Fitzmyer, 1993:489). Die werke van die Gees is gerig op die vernuwing van menswees en die bevryding van die mens uit die mag van die sonde.

'n Lied wat die betekenis van hierdie verse sou kon omdig, kan die volgende belangrike temas aanraak: die beheersing deur die Gees, die verhouding Christus en die Gees, die stryd tussen die sondige natuur en 'n lewe beheers deur die Gees, die uitkoms van beheersing deur die sondige natuur (die dood) en die gevolg van beheersing deur die Gees (lewe en vrede). 


\subsection{Lewe deur die Gees (Rom. 8:9-11)}

Met nadruk rig Paulus hom tot die gemeente, want die gemeente laat hulle deur die Gees beheers. Hulle lewensfeer, lewenselement is die Gees. Hierdie lewensfeer is nie 'n mistieke ervaringstoestand nie, want die gemeente is in die magnetiese kragveld, in die magsgebied, onder heerskappy van die Gees. Dié wat buite Christus leef, is egter in die magsgebied van die sondige natuur. Dit gaan dus vir die gemeente om 'n nuwe bestaanswyse wat deur die Gees van Christus bepaal word (Ridderbos, 1959:175). Paulus motiveer die gemeente verder deur hulle te herinner dat die Gees van God in hulle woon. Die uitdrukkings "beheer deur die Gees" (vó $\mu$ os

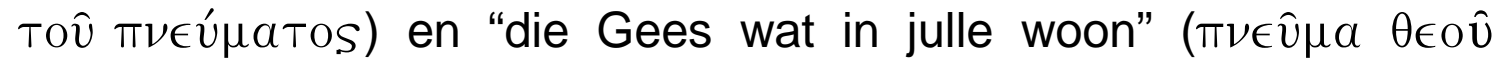

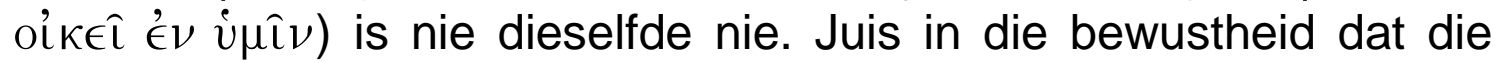
Gees in hulle woon, is hulle oortuig dat hulle deur die Gees beheers word (Lambrecht, 1992:101). Die woon van die Gees in die gemeente moet verstaan word in die sin van 'n blywende in-besitneem van die gemeente deur die Gees. Dit is die vervulling van die Ou-Testamentiese woon van God in die midde van die volk (vgl. 2 Sam. 7:5). Die feit dat die Gees blywend in die gemeente woning gemaak het, is immers dié kenmerk van die Nuwe-Testamentiese gemeente (Mounce, 1995:178). Die gemeente is God se huis, die tempel waarin $\mathrm{Hy}$ woon. Hierdie inwoning geld veral die wyse waarop God gemeenskap met sy gemeente het. Die Gees is die verbindingskakel tussen Christus en die gelowige in elke opsig. Daarom is die besit van die Gees dié kenmerk dat iemand aan Christus behoort.

In Romeine 8:9 is die eenheid van die opgestane Christus en die Gees ' $n$ eenheid wat eskatologies van aard is. Dit is ' $n$ eenheid wat betrekking het op die nuwe aeon (Versteeg, 1971:362). Die inwoning van die Gees in die gemeente is so ' $n$ wesenlike kenmerk dat Paulus daaraan toevoeg: wie nie die Gees van Christus het nie, behoort nie aan Christus nie. Die liggaamlike bestaan is nog aan die dood onderwerp (Rom. 8:10) en kragtens die eenheid met Christus mede in die dood inbegrepe, maar die Gees is lewe (Fitzmyer, 1993: 490). Die Heilige Gees skenk nuwe lewe vanweë die geregtigheid (vryspraak) wat Christus se opstanding gebring het. Die gelowiges moet nog sterwe omdat hulle in Christus inbegrepe is en daarom in sy spore moet volg.

In Christus lê ook die waarborg van die opstanding van die liggaam deur die krag van die Gees, wat ook in Christus se opstanding werksaam was. In Romeine 8:11 word die sekerheid van die lewendmaking van die sterflike liggame op twee gronde gestel: 
Christus is opgewek en in die Gees besit die gelowige reeds die nuwe lewe (Versteeg, 1971:377). Die lewe onder beheer van die Gees is die lewe van die nuwe skepping. Wanneer die sterflike liggame van gelowiges ter wille van die Gees wat in hulle woon, lewend gemaak sal word, sal die gelowiges gelykvormig wees aan die beeld van die opgestane Christus (Dunn, 1988:445). Die Heilige Gees is die waarborg dat die liggaam eenmaal in die opstanding vernuwe sal word.

Ook in hierdie verse (8:9-11) kom aangrypende temas vir 'n pneumatologiese lied na vore: Die Gees gee lewe, die Gees woon in die gemeente, die Gees word tegelyk genoem die Gees van God en die Gees van Christus, die verhouding tussen die drie Persone van die Drie-eenheid word op unieke wyse beskryf, en God maak ons sterflike liggame lewend deur die Gees. Die Christelike lewe is lewe in die Gees, 'n lewe wat gevorm, gerig en verryk is deur die Gees.

\subsection{Kinders van God deur die Gees (Rom. 8:12-17)}

Omdat die gelowiges in Christus onder die heerskappy van die Gees gekom het, het hulle dienstigheid aan die sonde tot 'n einde gekom. Al die bose werke van die sondige natuur moet gedood word, maar die gelowiges kan dit nie uit eie krag doen nie. Dit geskied onder leiding en deur die krag van die Heilige Gees. Die gedagte wat hieraan ten grondslag lê, is: wees dienstig aan die Gees om volgens die Gees te lewe (Fitzmyer, 1993:492). Die gelowiges sal lewe wanneer hulle die sondige praktyke deur die Gees doodmaak en hulle deur die Gees laat lei.

Die leiding en beheersing deur die Gees gee aan die gelowiges nog 'n verlossingsgeskenk: hulle is kinders van God (oîtor vios $\theta \in O \hat{v}$ $\epsilon i \sigma(\nu)$. Kindskap is ten nouste verbind aan die inwoning en werking van die Gees wat in vers 14 beskryf word as "hulle deur die Gees laat lei". Kindskap kan nooit deur wetsonderhouding verkry word nie; dit is 'n genadegawe. Die leiding van die Gees is nie 'n voorwaarde vir kindskap nie, maar is die belangrikste kenmerk van die kind van God. Hierdie leiding beteken niks minder as dat die Heilige Gees die bestuur van hulle lewe oorneem nie (Mounce, 1995:181). Wie deur die Gees van God gelei word, dien God vanuit die verhouding van 'n kind tot sy Vader.

Dat die Gees en kindskap ten nouste met mekaar saamhang, word in Romeine 8:15 verklaar vanuit die aard en werking van die Gees. Die Heilige Gees bevry die gelowiges van die gees van sondeverslaafdheid wat hulle gedurig weer laat vrees en in angs laat lewe. 
Net so lei die strewe om in eie krag verlossing te probeer verwerf tot onsekerheid en vrees. Daarteenoor is die Gees van Christus die Gees van kindskap, waarin nie plek is vir slaafse vrees nie, maar waar vryheid en kinderlike vertroue heers. Die begrip vios dui veral op die status van die kind wat hy/sy verkry wanneer so iemand van buite as kind in 'n gesinskring opgeneem word. Die konsekwensie van aanneming in die tyd van die Romeine was ingrypend: so 'n kind verloor alle regte in die ou gesin, ontvang al die regte van 'n wettige kind, word erfgenaam saam met die ander kinders, word van vorige skuld kwytgeskeld, maak 'n totaal nuwe begin en is in die oë van die wet volledig kind van die nuwe vader (Barclay, 1975:106).

Die Gees herinner en versterk die sekerheid van kindskap by die gemeente, want dit is deur Hom wat hulle roep: $A \beta \beta a \dot{o}$ тати́ $\rho$. Hierdie verbinding van gebedstaal met die Gees (vgl. ook Gal. 4:6) gee aan die gebruik van die Vadernaam sy onaantasbare en profetiese betekenis (Mounce, 1995:182). Die aanroep van die vader $(\mathrm{A} \beta \beta \alpha)$ gee nie alleen uitdrukking aan die subjektiewe ervaring van die gelowige om God so intiem te kan aanspreek nie, maar veral aan die werk van die Gees wat hede en toekoms verbind. Die Gees sit die werk van Christus op aarde voort en die gebedsroep deur die Gees verkry daardeur die betekenis van 'n belydenis, wat naas die hede ook die toekoms omvat (Open. 22:17; Ridderbos, 1959:181). Wie bevry is van die vrees vir die oordeel en ingelei is in die verborge omgang van God met ons deur die Gees, mag God as Vader aanspreek. 'n Hart wat hierdie woord kan sê, is vervul met die liefde van God tot die gelowige.

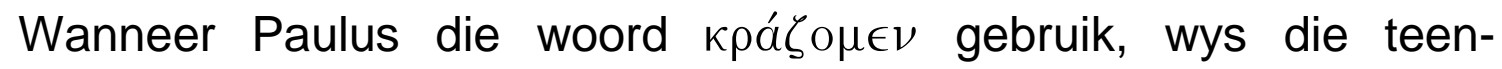
woordige tyd van die werkwoord dat die gemeente van Rome hierdie uitspraak reeds ken en gewoond was om God as $\mathrm{A} \beta \beta \alpha$ o $\pi a \tau \eta ́ p$ aan te spreek. Dit is 'n aanroep in nood met 'n proklamerende aard. In die Ou Testament word God nooit in gebed as $\mathrm{A} \beta \beta a$ aangespreek nie en dit was verrassend (skokkend) dat Jesus God as my Vader aangespreek het. Die woord $A \beta \beta a$ druk dus ' $n$ baie nou vertrouensverhouding uit. Daarom kan die gelowige alleen so tot God roep deur die Gees, want hy/sy kan nie self die krag en moed daartoe hê nie. Die wisselwerking van die Gees in hierdie opsig is aangrypend: in Galasiërs 4:6 roep die Gees in die hart van die gelowige en in Romeine 8:15 roep die gelowige deur die Gees (Versteeg, 1973:21).

Die Heilige Gees tree hier op as Getuie (Rom. 8:16). In die Romeinse wêreld van destyds was daar sewe getuies by die aannemingseremonie teenwoordig en so is die reg van die aangenome 
persoon gewaarborg en daarmee saam sy erfdeel. So is die Heilige Gees self die getuie van die gelowige se aanneming in die huisgesin van God (Barclay, 1975:107). Die Gees getuig met die gelowiges se gees dat hulle kinders van God is, wat beteken dat die Gees die gelowiges in hulle harte oortuig dat die getuienis van hulle eie gees, naamlik dat hulle kinders van God is, waar is. Omdat hulle kindskap nog nie duidelik sigbaar is nie, het hulle die medegetuienis van die Gees nodig. Die invloei van die Gees se getuienis in die getuienis van die gelowige, stel hulle in staat om deur sy krag te getuig. So word die getuienis van God se vaderskap en hulle kindskap in hulle lewend gehou (Fitzmyer, 1993:501). Die woord vir kinders ( $\tau$ ́́kva) is hier anders as in vers 14 en dui meer op die eenheid in gemeenskap met die Vader: die kind is uit die vader gebore en deel in sy lewe. Kinders is ook erfgename en mede-erfgename met Christus. Soos Christus uit lyde tot heerlikheid verhoog is, so sal dié wat in Hom is, nie net in sy lyde, maar ook in sy heerlikheid deel.

Romeine 8:12-17 bied aangrypende liedstof. 'n Beryming van hierdie gedeelte sal die volgende van die Persoon en werk van die Gees by die sangers inskerp: die innige samehang tussen die Gees en kindskap, kinders van God deur die Gees, die leiding van die Gees as kenmerk van kindskap, nie meer dienstig aan die sonde nie, die aanroep Abba, Vader en die Gees as getuie wat sekerheid oor die gelowige se kindskap gee.

\subsection{Hoop deur die Gees (Rom. 8:18-25)}

In hierdie gedeelte word die Gees se werk aan die "reeds" en die "nog nie" verbind, dit wil sê aan die Christelike hoop. Die gemeente en buitestanders kan nog nie sien dat die gelowiges kinders van God is nie, want die lyding, verganklikheid en nietigheid van alles bedek die heerlikheid van hulle kindskap. Maar te midde van die lyding en swaarkry wat hulle nou beleef, het hulle die sekerheid van 'n heerlike toekoms. Paulus minimaliseer nie die lyde nie, maar in vergelyking met die heerlikheid wat wag, kan dit nouliks in aanmerking kom. Hy gee vier motiverings waarom die huidige lyding nie teen die komende heerlikheid opweeg nie:

- Die skepping se gespanne verwagting en versugting dat God bekend sal maak wie sy kinders is (8:19-22)

- Die gemeente, wat die Gees as eerste gawe reeds ontvang het, se versugtende verlange dat God bekend sal maak dat Hy hulle as sy kinders aangeneem het (8:23-25) 
- Die rol van die Gees - wat in die gemeente woon - in die tussentyd terwyl ons wag dat God openbaar wie sy kinders is: soos die skepping en die kinders van God sug die Heilige Gees ook in afwagting op die voleinding (8:26-27)

- Die sekerheid dat God op grond van sy uitverkiesende liefde sy werk enduit sal volvoer en die gemeente sal verheerlik (8:28-30; Van Rensburg, 1982:165).

Die skepping en die skepsel is in voortdurende verset teen die verganklikheid en worstel met krag daarteen, want God het die belofte van hoop gegee. Die woorde oú $\mu$ óvov $\delta \dot{\varepsilon}$ wys op 'n klimaks in die gedagtegang, want die sugte van God se kinders is meer as die sugte van die skepping. Hulle het reeds die Gees ontvang en vertoon die beeld van 'n verwagtende en hopende lewe onder leiding van die Gees. Die gelowiges wat reeds met die Gees begenadig is, moet in hulle huidige bestaan die verlange na verlossing aanwys.

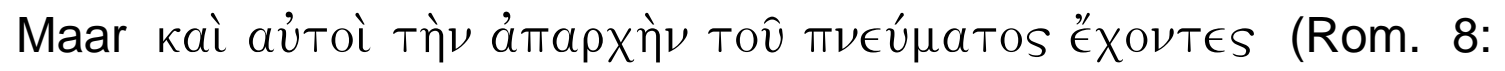
23) sug by onsself. Hierdie sug by hulleself is nie in stryd met die gawe van die Gees nie, maar eerder teken van die verwagting van hulle openlike aanneming tot kinders; die verlossing van die huidige bestaanswyse van die liggaam. Lyde word hier beskryf in die kategorie van verlossing. Een van die kerngedagtes van Paulus se prediking oor die Gees is áma $\chi \grave{\eta}$, wat stam uit die offerwetgewing van Israel, sy eerstelingsoffer (Mounce, 1995:185). Die eersteling dien dan tegelyk as erkenning dat die hele oes eintlik aan die Here behoort en as sekerheid dat die volle oes ingesamel sal word.

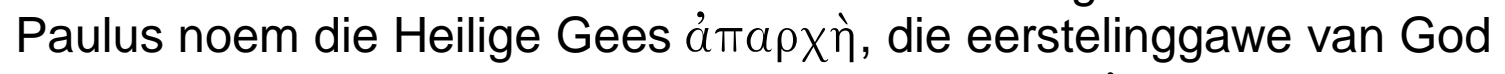
aan sy kinders. Nou is dit nie die mens wat 'n áma $\chi \grave{\eta}$ offer nie, maar in 'n omgekeerde rol ontvang die kind van God nou die

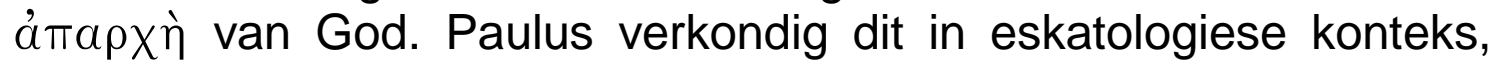
want die skepping sowel as die kinders van God sug en verlang te midde van sondeverval na die dag waarop alles nuut gemaak sal word. Dan sal die kindskap bekend gemaak word, die liggame verheerlik word en sal die kinders saam met Christus as erfgename van God die volle heerlikheid erf (Coetzee, 1984:237). Die Gees as $\dot{a} \pi \alpha \rho \chi \grave{\eta}$ is die eerstelinggawe van die toekomstige eeu, die eerste vrug van die volle oes, die waarborg dat die gelowiges die volle erfenis sal beërwe, die bron van sekerheid dat die nuwe eeu vir die gelowiges reeds begin deurbreek het, maar ook die bron van verlange na die voleinding (vgl. Fitzmyer, 1993:510). 
Dit is dus die spanning tussen die "reeds" en die "nog nie", wat kenmerkend van die Christelike hoop is. Die Gees en die hoop is ten

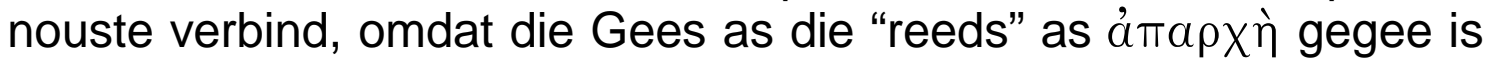
en die waarborg is dat die "nog nie" sal aanbreek. Die aard en eienskappe van die hoop lê nie in wat gesien word nie, maar in die uitsien na die heerlikheid wat in die Gees verseker is. Hierdie vastigheid van die hoop gee aan die gemeente volharding.

Daar is 'n pneumatologiese lied oor hierdie deel wat ook verse 26 en 27 insluit (Skrifberyming 20, waarvan die melodie moeilik singbaar is). In die lied kom verskeie fasette van die openbaring van die Heilige Gees na vore. Daar is nog ruimte vir digters om hierdie ryk gedeelte om te dig en veral die wonder van die eskatologiese werk van die Gees in liedvorm vas te lê. Die gedagte van die Gees as

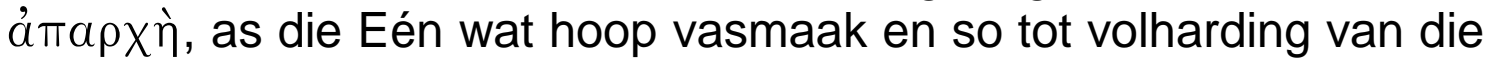
gemeente begelei, is belangrike temas waardeur gelowiges mekaar in die lied kan bemoedig.

\subsection{Bid deur die Gees (Rom. 8:26, 27)}

Paulus het in die sug van die skepping en in die sug van die gelowiges iets van die komende verlossing gehoor. Nou sluit hy met

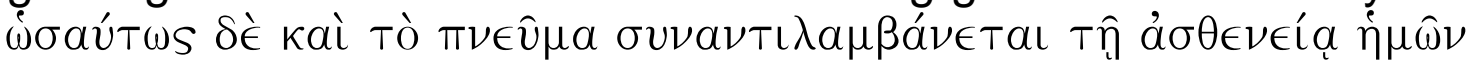
daarby aan en plaas hy die werk van die Gees in dieselfde verband as die reikhalsende uitsien van die hele skepping en die volhardende hoop van die gemeente (Smith, 1998:37). Dit gaan in hierdie twee verse oor die verhouding van die Heilige Gees en die gebed in die lewe van die Christen. 'n Grondtrek van die gebed in hierdie tyd is dat dit 'n sug is vanweë die "nog nie", 'n sug om die voleinding. Juis in die gebed waarin hulle hulle nood uitspreek, word hulle swakheid geopenbaar. Die bestaanswyse van die gelowige word uitgedruk met $a \dot{\sigma} \theta \epsilon \nu \in \hat{i} \alpha$, as deelhê aan die lyde van die teenwoordige tyd. Die werkwoord $\sigma v \nu \alpha \nu \tau \iota \lambda a \mu \beta a ́ v \in \sigma \theta a$ i is 'n bikompositium, 'n werkwoord waaraan twee voorsetsels toegevoeg is. Die eerste een $\sigma v \nu$ versterk die tweede $\hat{\alpha} \nu \tau \iota$ wat die helpende ondersteuning tegelyk as plaasvervangende ondersteuning karakteriseer (Lambrecht, 1992:124). Die "te hulp kom" van die Gees wat 'n plaasvervangende konnotasie het, word in verband met die gebed nader gekonkretiseer as 'n pleitrede met onuitspreeklike versugtinge (Versteeg, 1973:27).

Die bedoeling is nie dat die Gees buite om die mens tot God bid nie; want gebed is die werking van die Gees in die harte van die gelowiges. Dit is sy gebed uit die hart tot God waarin Hy die swak menslike gebed 'n vertolking gee wat in ooreenstemming is met die 
volkome verlossing waarop die gemeente hoop en waarvoor hulle bid. Die Gees $v \pi \epsilon \rho \in \nu \tau v \gamma \chi \alpha ́ v \in \mathrm{l}$ vir die gelowige en doen so iets wat die gelowige nie kan doen nie. Die gebed van die gelowige kan nie ten volle beantwoord aan en ooreenstem met die voorneme van God nie. Die gebed wat na sy aard 'n gebed met onuitspreeklike versugtinge is, lê nie binne menslike moontlikhede nie. Op hierdie punt tree die Gees vir die gelowiges in (Versteeg, 1973:30). God verstaan die onuitspreeklike versugtinge van die Gees, omdat Hy daarin die volvoering van sy eie voorneme hoor. God deursoek die harte en vind daarin die sukkelgebed van die gelowige, maar ook die bedoeling van die Gees. Omdat die Gees vra wat God wil, is verhoring seker (Wu, 1993:13). Die Gees is dus die gebedsmiddelaar, want die Gees gee aan die gebed van die gelowiges inhoud wat ooreenkomstig die wil van God is.

Die armoede van die gebed, ons á $\sigma \theta \in \nu \in i ́ a$, is van so 'n radikale aard dat dit nie oorwin sal word solank as wat die gelowige in hierdie wêreld leef nie. Net die intrede van die Gees kan gelowiges uit hierdie gebedsnood red. Wanneer gelowiges bewus is van hulle swakheid waarin die Gees hulle te hulp moet kom, gee dit aan die gebed enersyds beskeidenheid en andersyds vertroue.

Skrifberyming 20:7, 8 gee uitdrukking aan die troos van Romeine $8: 26,27$. Hierdie deel is egter nie alleen troosryk vir gelowiges nie, maar bied ook onderrig oor die gebed. Temas wat hieruit na vore kom, is die algemene swakheid van die gelowige, die aangrypende te hulp kom deur die Gees, die plaasvervangende bid, die bid in die hart van die gelowige, en uiteindelik die innige band van die Heilige Gees en die gebed.

\section{Samevattende basisteoretiese perspektiewe op die pneumatologiese lied (Rom. 8)}

Enkele basisteoretiese perspektiewe wat na vore kom, is die volgende:

- Die volle Raad van God, ook die Persoon en werk van die Heilige Gees, moet deur die berymings van toepaslike Skrifgedeeltes voortdurend die aandag van die kerk se digters kry.

- Daar is vanuit Romeine 8 'n behoefte en noodsaak aangedui om meer Skrifberymde liedere oor die Heilige Gees beskikbaar te hê.

- Die liedere oor die Persoon en werk van die Heilige Gees kan die aard hê van lofprysing, onderrig oor die Gees en sy werk, 
afwysing van verkeerde lewenstyl (bv. beheer deur die sondige natuur), vertroosting en gebedsbemoediging.

- Liedere oor die Persoon en werk van die Gees kan die belydenis oor die Gees bewaar en aktualiseer en kan die belydenis op 'n unieke wyse in die hart van twyfelaars en ongelowiges indra.

\section{Empiriese gegewens in drie sangbundels oor die pneumatologiese lied}

Voordat enkele voorbeelde van Skrifgedeeltes vir die beryming van die pneumatologiese lied gegee word, moet eers empiries ondersoek word wat die omvang en aard van die lied is in hedendaagse gereformeerde kerkgemeenskappe. Die doel van empiriese ondersoek is altyd om kennis te genereer wat dit moontlik sal maak om 'n huidige en moontlik onbevredigende situasie te verander in 'n meer aanvaarbare. Praktiese Teologie het veral in hierdie geval te doen met die kommunikatiewe handelinge van die lied in die huidige tyd en dit kan alleen deur middel van 'n empiriese metode ondersoek word (Heitink, 1999:223-225; Heyns \& Pieterse, 1990:73). Vir die doeleindes van die empiriese ondersoek is drie liederebundels gekies: Psalmboek ${ }^{1}$ (2003), Liedboek van die kerk ${ }^{2}$ (2001) en die Psalter Hymnaß (1987). Al drie bundels word deur gereformeerde kerkgemeenskappe gebruik en die vergelyking is dus nie tussen gereformeerde kerke en charismatiese of pinksterkerkgemeenskappe nie.

\subsection{Die omvang van die pneumatologiese lied in die Psalms}

In slegs drie Psalms word regstreeks na die Gees verwys. In Psalm 51 is die smeking in die gebed van skuldbelydenis dat die Heilige Gees nie van die digter weggeneem moet word nie. In al drie die bundels kom hierdie gedagte duidelik na vore en die woorde stem

1 Die Sinode van die Gereformeerde Kerke in Suid Afrika het in Januarie 2003 besluit om 'n nuwe liederebundel (genoem Psalmboek) uit te gee. Die bundel het in Oktober 2003 verskyn en bevat die 1936-beryming en 2001-omdigting van die Psalms en sowat 79 Skrifberymings. Die voorlopige kopie van hierdie bundel is vir hierdie ondersoek gebruik.

2 Die Liedboek van die Kerk bevat die 2001-omdigting van die Psalms en ongeveer 450 ander liedere, waarvan sommige Skrifberymings is. Die bundel word deur die NG, NH en AP Kerke gebruik.

3 Die Psalter Hymnal bevat die 150 Psalms, 85 Skrifberymings (Bible songs) waarvan enkeles oor die Psalms handel en 400 liedere (hymns). Dié bundel word onder andere deur die Christian Reformed Church of America gebruik. 
feitlik ooreen. In Psalm 139 bely die digter dat God alomteenwoordig en alwys is. In die 1936-beryming en die Psalter Hymnal word dit in die lied nagesê, maar die 2001-omdigting het nie hier 'n verwysing na die Gees nie. Die Gees word aangeroep as God: "Waar, God, kan ek U ontvlug?" Dieselfde geld vir Psalm 143: die digters van die 1936-beryming en die Psalter Hymnal vertolk die Psalm as 'n smeking dat die Gees hom op 'n goeie of veilige pad sal lei. Sonder om die naam van die Gees te noem, vertolk die 2001-omdigting die gedagte ook met: "Leer my u wil en lei my".4 Vanuit die bedeling van die Ou Testament gesien, is dit nie vreemd nie dat daar min psalms is waarin die Gees ter sprake kom en wat die kerk dus geleentheid gee om hierdie soort lied te sing. Die openbaringshistoriese ontwikkeling van die Ou-Testamentiese monoteïsme na die NuweTestamentiese Christologiese monteïsme na die vroeë kerk se trinitariese monoteïsme, moet in gedagte gehou word.

\subsection{Die omvang van die pneumatologiese lied in die Skrifberymings}

Slegs die Psalmboek en die Psalter Hymnal tipeer sekere liedere as Skrifberymings of Bible songs. Die Liedboek van die Kerk bevat ook Skrifberymings, maar plaas hulle nie in 'n afsonderlike kategorie nie. Met die uitbreiding van die Skrifberymings in 2003 bevat die Psalmboek 79 Skrifberymings en in 11 daarvan word die naam van die Gees (Heilige Gees) genoem. Sewe ander bevat die refrein wat in die briewe aan die sewe gemeentes in Openbaring geskryf is: Luister na wat die Gees vir die gemeente sê. Twee Skrifberymings (13 en 14) handel uitsluitlik oor die Persoon en werk van die Gees: die een (14) besing die belofte dat die Gees uitgestort sal word (Eseg. 36) en die ander (13) is 'n lied eerstens oor die geskiedenis van die uitstorting (Hand. 2:1-4) en bevat tweedens grepe uit Petrus se preek by die uitstorting. Persentasiegewys uitgedruk, kom verwysings na die Gees regstreeks in $14 \%$ van die Skrifberymings voor.

Wat die Psalter Hymnal betref, is daar 85 Bible songs en in sewe van die Bible songs kom die Gees regstreeks ter sprake. Twee van die sewe handel uitsluitlik oor die Gees: die belofte van die uitstorting van die Gees kom voor in die beryming van Joël 2 en Galasiërs 5:22, 23 is berym om die vrug van die Gees te besing. Persentasiegewys uitgedruk, is die Gees in ongeveer $8 \%$ van die

4 Die 1936-omdigting koppel die Gees ook aan Psalm 33, 104 en 106, maar die oorweldigende getuienis van Bybelverklaarders toon aan dat hier nie na die Heilige Gees verwys word nie. 
Bible songs ter sprake. Die Psalter Hymnal bevat ook himnes waarin heelwat meer liedere oor die werk van die Gees voorkom.

Hieruit kan afgelei word dat Skrifberymings oor die Persoon, geskiedenis en werk van die Heilige Gees in die liedereskat van die Psalmboek en Psalter Hymnal (Bible songs) baie min voorkom.

\subsection{Die omvang van die pneumatologiese lied in ander kerklike liedere in die Liedboek van die Kerk en die Psalter Hymnal}

In die Psalmboek kom daar nie van hierdie liedere voor nie. In die Liedboek van die Kerk is daar 450 liedere wat in die erediens gebruik kan word en in 105 daarvan kom verwysings na die Gees ter sprake. Vyftien van die liedere handel uitsluitlik oor die Persoon en werk van die Gees en word aan die viering van Pinkster verbind. Persentasiegewys uitgedruk, is die Gees in ongeveer $23 \%$ van die liedere ter sprake. In die Psalter Hymnal is daar 400 ander liedere wat in die erediens gebruik word en in 75 kom die Gees ter sprake. Dertien van hierdie liedere handel uitsluitlik oor die Heilige Gees en die liedere word ook aan die viering van Pinkster gekoppel. Persentasiegewys uitgedruk, kom verwysings na die Gees in ongeveer $19 \%$ van die liedere voor.

Daar is dus meer liedere met 'n pneumatologiese inslag in die vrye (of Bybelgetroue) lied as in die Psalms of Skrifberymings, maar dit is nie 'n betroubare vergelyking nie. Die Psalmboek bevat nie vrye (of Bybelgetroue) liedere nie, behalwe twee liedere vir huislike gebruik. Die Liedboek van die Kerk sou met die Psalter Hymnal vergelyk kon word, maar omdat die fokus in hierdie artikel op riglyne vir omdigting van Bybelgedeeltes is, is so ' $n$ vergelyking nie relevant vir hierdie artikel nie.

\subsection{Die aard van die pneumatologiese liedere in die verskillende bundels}

Verskillende aspekte van die Persoon en werk van die Heilige Gees word in die drie bundels besing. Aan die hand van verskillende hooftemas sal gepoog word om die aard van die liedere vas te stel.

\section{- Liedere oor die Gees en die Drie-eenheid}

In die Psalmboek (PB) is daar drie Skrifberymings (Skr.) 5 (waarvan een die beryming van die Apostoliese Geloofsbelydenis is), in 14

$5 \quad$ PB Skr. 25:1; 48 en 27. 
liedere in die Liedboek (LB)6 en in 24 liedere uit die Psalter Hymnal $(\mathrm{PH})^{7}$ (waarvan twee berymings van die Apostolicum is en een van die Geloofsbelydenis van Nicea) word die Drie-eenheid besing. In die LB en die PH is liedere oor God die Vader en Christus wat die Gees gee, die Gees wat die gelowige begelei om God "Vader" te noem en te bely dat Jesus "Here" is. Die noue band tussen die Gees en Jesus Christus kom ook aan die orde. 8

\section{- Liedere oor die Persoon van die Heilige Gees}

Daar is 'n enkele Psalm wat getuig van die Gees wat alomteenwoordig en alwetend is (Ps. 139:3). Uit die LB en PH word die volgende eienskappe van die Gees beskryf: die Gees gaan van die Vader en die Seun uit, die Gees is die Trooster en Advokaat, die Gees is die Gees van waarheid, die Gees is ons pand en waarborg, die Gees is die Gees van seëninge. ${ }^{9}$ Daarom moet die gelowige vervul word met die Gees en aan die Heilige Gees lof en eer toebring. 10

\section{- Liedere oor die Gees en die openbaringsgeskiedenis}

In baie liedere kom die werk van die Gees in die openbaringsgeskiedenis ter sprake. Oor die Gees se teenwoordigheid by die skepping en die belofte van die uitstorting van die Heilige Gees in die Ou Testament word gesing. ${ }^{11}$ Die Gees se werk in die ontvangenis van Jesus, die lei van Jesus na die woestyn en die blaas van Jesus op sy dissipels om aan hulle die Gees te gee is gedagtes wat verteenwoordig is in die liedere wat oor die geskiedenis van die Gees en Jesus handel.12 Die uitstorting van die Heilige Gees, die Gees as eerste gawe van die nuwe bedeling (die

$6 \quad$ LB $161 ; 169: 2 ; 180 ; 188: 3 ; 257: 3 ; 289: 1 ; 290: 1,4 ; 316 ; 322: 4 ; 445 ; 450: 1,2$; 456:3; 475:2; 597:5.

$7 \quad$ PH 294:1, 4; 273:5; 283; 284; 322:2; 327:5; 332; 364:6; 389:3; 404:4; 441:4; $444: 7 ; 454: 3 ; 504: 4 ; 505: 7 ; 518-520 ; 618: 4 ; 634-638$.

$8 \quad$ LB 154:1; 244:3; 341:3; 323:1, 2; 327:1; 411:2; PH 415:3; 536:2; 625; 507.

9 Uitgaan Vader en Seun: LB 430:6; 434; PH 252:3; Trooster: LB 430:2; 434:1; 442:1; 447:3; 454:3; PH 416; 450:3; 495:3; Waarheid: LB 496:2; PH 422; Waarborg: PB Skr. 24:7; LB 407:2; 448:4.

10 Vervul: LB 354:1; PH 424; 521; 536:3.

11 Skepping: LB 459:1; PH 415:1; Belofte: PB Skr. 14:1, 2; PH 201:1; 274:4.

12 Ontvangenis: LB 322:2; PH 336:2; Woestyn: PH 415:3; Blaas: PH 415:3. 
laaste bedeling) en die Gees se roep saam met die kerk as bruid dat Christus weer moet kom, word in liedere beskryf waarin die Gees se werk in die geskiedenis ter sprake kom.13

\section{- Liedere oor die Gees en die kerk}

In al drie bundels kom liedere voor oor die Gees en die kerk. Hierdie liedere hanteer verskillende temas. So is daar liedere wat sing van die Gees se inwoning in die kerk, liedere wat bid dat die Gees in die kerk sal werk en liedere waarin die Gees se boodskap aan die kerk beskryf word.14 Oor die Gees se werk in die gemeente kom liedere voor oor die Gees wat insig gee in die Woord (die verstand verlig en die innige verhouding tussen die Gees en die Woord), die Gees en koinonia, en die Gees wat van die kerk sy getuies maak. ${ }^{15}$

\section{- Liedere oor die Gees en ons geloofslewe}

Hierdie liedere se inhoud betrek die spektrum vanaf die wedergeboorte en die skenk van nuwe lewe deur al die prosesse van geloofsgroei. Oor die wedergeboorte, die skenk van nuwe lewe, die herskepping van die hart is daar baie liedere. Hierdie selfde Gees verbind ons - sonder dat ons ook hieraan 'n aandeel het - deur die geloof (wat die Gees wek) aan Christus en verseker ons dat ons kinders van God is. ${ }^{16}$ In geloofsgroei en groei in sondebesef en heiligmaking, saam met gehoorsaamheid en die gebed dat die Gees die gelowige in alles sal lei, is die Gees se werk onontbeerlik. ${ }^{17}$

13 Uitstorting: PB Skr. 13; Eerste gawe: PB Skr. 20:5; Skr. 13; Kom Here Jesus: PB Nuwe Skrifberyming: Gees en bruidsroep; LB 594:2.

14 Inwoning: LB 166; 207; 216:3; 308:5; 432:2; 441:2; 445; 447:3; 449; 495:1; 518:1; 582:4; 593:2; Gebed Gees se werk: PB Nuwe Skrifberyming: Gebed vir die kerke; PH 516:1; 517; Boodskap: PB Skr. 38-44; LB 255:2; 258:1; 524.

15 Verligting: LB 151:2; 157:2; 323:2; 431:2; 434:2; 442:1; 443:1,5; 448:4; PH 255:3; 278:1-3; 280:2; 281:5; 322:1; 415:2; 416; 423; Koinonia: LB 291:2; 520:1; PH 415:1; 418; 426; Getuies: PB Skr. 11:2; LB 437:1; 441:1; PH 492:3.

16 Nuwe lewe: LB 164:2; 407:2; 430:1; 435:1; 436:1; 438:1; 439:1; 441:2; 444; 478:1; PH 416; 420; 422; 490:1, 2; 494:1; 532:1, 2; Verbind: PH 549; Kinders: PB Skr. 24:7; LB 244:3; 292:2; 297:3; 432:1; PH 252:3; 269:1-3; 418; 422.

17 Oortuig van sonde: $\mathrm{PH} 418$; Smeking Gees nie wegneem as gevolg van sonde: PH, LB en PB: Ps. 51:5; Heiligmaking: LB 152; 154:2; 250:5; 269:1; 430:3; 441:1; 447:3; PH 420; 421; 423; 425; Gehoorsaamheid: PB Skr. 14:2; LB 294:3; 438:1; 441:2; 537:2; PH 415:2; Lei, begelei: LB 162; 168:2; 252:3; 269:1; 275:3; 283:1; 394:2; 449:3; 532:2; 537:2; 538:3; 571:4; PH 364:5; 445:3; 517. 
Dit is daarom byna vanselfsprekend dat daar ook liedere sal wees wat sal sing oor die Gees wat die geloof versterk en dat die Gees die gelowige se gelooflewe bring tot 'n hoogtepunt van lof, jubeling en aanbidding van God. 18

\section{- Liedere oor die Gees se genadige geskenke aan die mens}

Die grootste geskenk wat die Gees aan die gelowige kan gee, is dat Hy die gelowige van binne deur sy Woord regeer. Die Gees lei hom/haar in die waarheid en op die regte pad, gee gebedshulp aan die gelowige en deel nie net die pyn en sugte van die kind van God nie, maar bring ook genesing. ${ }^{19}$ Die Gees gee aan die gelowige liefde, krag, blydskap, vryheid, gawes, vrug, rus en vrede.20 Daar is ook liedere waarin die gelowige verseker word dat die Gees hulle erfenis verseël en hulle salf tot konings, priesters en profete.21

\subsection{Gevolgtrekking uit die empiriese ondersoek}

Uit die behandelde gegewens kan 'n beeld gevorm word oor wat die stand van die liedereskat oor die Persoon en werk van die Heilige Gees is. Die doel van die empiriese ondersoek was om hieruit vas stel stel of die huidige situasie bevredigend is en of daar vanuit die basisteorie sekere regstellings gemaak moet word. Omdat dit in hierdie ondersoek uitsluitlik handel oor die omvang en aard van die liedere wat as Skrifberymings kwalifiseer - en nie oor die vrye (of Bybelgetroue) lied nie - kan die volgende gevolgtrekkings gemaak word:

- Twee Skrifberymings handel uitsluitlik oor die Heilige Gees: oor die belofte van die Heilige Gees (Skr. 14) en die geskiedenis van die uitstorting (Skr. 13). Drie Skrifberymings besing die Drieeenheid (Skr. 25, 27 en 48) en een Psalm handel oor die Persoon van die Gees (die Gees is alomteenwoordig; Ps. 139).

18 Geloofsversterking: LB 430:1; 433:2; 445:4; 448:4; PH 417; 495:3; Loof: LB 215:3; PH 418.

19 Regeer: LB 287:4; 304:2; 430:5; 494:3; 541:1, 2, 3; Lei op regte pad: PB en PH Ps. 143:8; LB 168:2; 431:1; 440:4; 509; 512:2; 513:3; 558:4; PH 201:1; 286:3; 419; Gebedshulp: PB Skr. 20:7, 8; LB 431:1; 438:2; 452:3; 453:3; 535:1; PH 416; 421; Sug, genees: LB 309:3; 346:3; 562:2; 593:3; PH 491:3; 524:2.

20 Liefde: LB 334:3; 430:4; 489:3; PH 424; 426; 540:3; Krag: LB 422:3; 433:3; 445; PH 252:3; 271:3; 325:1, 4; 364:5; 417; 450:3; Blydskap: LB 305:2; 437:1; PH 364:5; 417; Vryheid: LB 232:1; PH 450:3; Gawes: LB 432:2; PH 523; Vrug: PH 224; Rus en vrede: LB 233; 451:3; 560:3; PH 417.

21 PB Skr. 24:7; LB 440; PH 225:5. 
Een Skrifberyming handel oor die Gees wat die waarborg is (Skr. 24). Twee Skrifberymings raak die openbaringsgeskiedenis aan (die Gees is die eerste gawe van die nuwe bedeling [Skr. 20] en die Gees roep saam met die kerk dat Christus gou moet kom [Nuwe Skrifberyming: Gees en bruidsroep]). In een Skrifberyming is 'n deel waarin gebid word dat die Gees die kerk sal bekragtig (Nuwe Skrifberyming: Gebed vir die kerke) en by die sondebelydenis 'n Psalm wat smeek dat God nie sy Gees van die sondaar moet wegneem nie (Ps. 51). 'n Skrifberyming waarin die gemeente bely dat die Gees die erfenis van die gelowige verseël (Skr. 24), is ook in die Psalmboek ingesluit. Hieruit kan afgelei word dat fasette van die Heilige Gees se Persoon en werk wel in berymings van Skrifgedeeltes voorkom.

- In die nagaan van die verskeie temas oor die Persoon en werk van die Gees wat nie in die huidige Skrifberymings voorkom nie, kan afgelei word dat daar ruimte is vir nuwe Skrifberymings wat oor aspekte soos die volgende kan handel: die Gees wat die gelowige begelei om God "Vader" en Jesus "Here" te kan noem, die innige band tussen Christus en die Gees, die Gees en die Woord, die Gees van Waarheid wat in die volle waarheid lei, die Gees wat in die kerk woon, die Gees en koinonia, die Gees wat ons getuies maak, die Gees en ons heiligmaking, die Gees wat lewe wek, wederbaar en geloof versterk, die Gees wat ons oortuig van sonde, die vrug en die gawes van die Gees, die vryheid van die gelowige onder die heerskappy van die Gees.

\section{Samevattende gevolgtrekkings en enkele voorbeelde van Skrifgedeeltes om as pneumatologiese liedere te berym}

In hierdie artikel is gepoog om uit Romeine 8:1-27 basisteoretiese perspektiewe vir die pneumatologiese lied na te gaan en om die omvang en aard van die pneumatologiese lied empiries in die Psalmboek, Liedboek van die Kerk en die Psalter Hymnal vas te stel. Uit die basisteoretiese ondersoek blyk dat daar 'n behoefte en noodsaak is aan toepaslike Skrifberymings oor die Persoon en werk van die Heilige Gees, want sommige eienskappe en funksies van die Gees wat van deurslaggewende belang vir die kerk en sy belydenis is, kom nie in huidige berymings van Skrifgedeeltes voor nie. Nuwe liedere oor die Persoon en werk van die Gees kan die belydenis oor die Gees bewaar en aktualiseer, die gemeente teen dwaling beskerm en die belydenis op 'n unieke wyse in die hart van twyfelaars en ongelowiges indra. 
Uit die empiriese gegewens kon 'n beeld gevorm word oor wat die stand van die liedereskat oor die Persoon en werk van die Heilige Gees is. Die doel van die empiriese ondersoek was om op grond van hierdie gegewens vas stel stel of die huidige situasie bevredigend is en of daar vanuit die basisteorie sekere regstellings gemaak kan word. Die volgende gevolgtrekking kan gemaak word:

- Daar is fasette van die Heilige Gees se Persoon en werk wat wel in berymings van Skrifgedeeltes voorkom. In die nagaan van die verskeie temas oor die Persoon en werk van die Gees wat nie in die huidige Skrifberymings voorkom nie, kan afgelei word dat daar ruimte is vir nuwe Skrifberymings.

Enkele van die belangrikste Skrifgedeeltes wat in aanmerking vir berymings kan kom, is die volgende: Romeine 8:1-8 (beheers deur die Heilige Gees); Romeine 8:9-11 (lewe deur die Gees); Romeine 8:12-17 (kinders deur die Gees); 1 Korintiërs 2:10-16 (Gees en God se openbaring); 1 Korintiërs 6:16-20 (tempel van die Heilige Gees); 1 Korintiërs 12:4-6 (die Drie-enige God en sy werk); 1 Korintiërs 12:7-11 (gawes van die Gees); 2 Korintiërs 3:17-18 (verhouding tussen Christus en die Gees); Galasiërs 5:22 (vrug van die Gees); Efesiërs 5:18-21 (vervul met die Gees); Johannes 3:3-8 (wedergebore deur die Gees); Johannes 14:16, 17, 25, 26; 15:26, 27; 16:715 (die Gees as Parakleet en Gees van die waarheid); 1 Johannes 5:6-12 (die Gees as God se groot Getuie).

\section{Geraadpleegde bronne}

BARCLAY, W. 1975. The letter to the Romans. The daily study Bible. Edinburgh: The Saint Andrew Press.

BINGLE, J.P. 2000. Die verhouding tussen openbaring, dogmavorming en doksa-uiting in die liturgiese lied. Potchefstroom: PU vir CHO. (Th.M.verhandeling.)

COETZEE, J.C. 1984. Die Heilige Gees in die prediking van Paulus. (In Du Toit, A.B., red. Handleiding by die Nuwe Testament. Band V. Die Pauliniese Briewe: Inleiding en Teologie. Pretoria: N.G. Kerkboekhandel Transvaal. p. 234-255.)

COETZEE, J.C., red. 1986. Glo - en jy sal lewe! Die brief aan die Romeine. Vir preeklees en Bybelstudie. Potchefstroom: EFJS.

DE KLERK, B.J. \& JANSE VAN RENSBURG, F.J. 1999. Preekgeboorte. 'n Handleiding vir Gereformeerde eksegese en prediking. Potchefstroom: Fakulteit Teologie, $\mathrm{PU}$ vir $\mathrm{CHO}$.

DUNN, D.G. 1988. Romans 1-8. Word Biblical Commentary. Volume 38. Dallas: Word Books.

FITZMYER, J.A. 1993. Romans. A new translation with introduction and commentary. The Anchor Bible. Volume 33. New York: Doubleday. 
HEITINK, G. 1999. Practical theology: history, theory and action domains. Translated by Reinder Bruinsma. Grand Rapids: Eerdmans.

HEYNS, L.M. \& PIETERSE, H.J.C. 1990. Eerste treë in die Praktiese Teologie. Pretoria: Gnosis.

JANSE VAN RENSBURG, F.J. 1982. Die ontleding van sintaktiese struktuur in die Griekse Nuwe Testament. Die ontwerp van 'n metode, geïllustreer met Romeine 8. 'n Hermeneutiese studie. Frankfort: Fiksona.

LAMBRECHT, S.J. 1992. The wretched "I" and its liberation. Paul in Romans 7 and 8. Louvain: Eerdmans.

MALAN, F.S. 1998. Church singing according to the Pauline epistles. Neotestamentica, 32(2):509-524.

MOORES, J.D. 1995. Wrestling with rationality in Paul. Romans 1-8 in a new perspective. Cambridge: University Press.

MOUNCE, R.H. 1995. Romans. The New American Commentary. Volume 27. USA: Broadman \& Holman.

RIDDERBOS, H. 1959. Aan de Romeine. Commentaar op het Nieuwe Testament. Kampen: Kok.

SHELT, C. 1996. Toward a Biblical theology of music in worship. The Reformed Theological Review, 55(2):67-80.

SMITH, G. 1998. The function of "likewyse" (osautos) in Romans 8:26. Tyndale Bulletin, 49(1):29-38.

VERSTEEG, J.P. 1971. Christus en de Geest. Een exegetisch onderzoek naar de verhouding van de opgestane Christus en de Geest van God volgens de brieven van Paulus. Kampen: Kok.

VERSTEEG, J.P. 1973. De Heilige Geest en het gebed. Apeldoornse studies, no 6. Kampen: Kok.

WEDDERBURN, A.J.M. 1991. The reasons for Romans. Minneapolis: Fortress.

WU, J-L. 1993. The Spirit's intercession in Romans 8:26-27. An exegetical note. Expository Times, 105:13.

Lys van afkortings:

LB - Liedboek van die Kerk

$\mathrm{PH}-$ Psalter Hymnal

PB - Psalmboek

Skr. - Skrifberyming

\section{Kernbegrippe:}

pneumatologiese lied: Romeine 8

empiriese gegewens: pneumatologiese lied

\section{Key concepts:}

pneumatological hymns: Romans 8

empirical material: pneumatological hymns 
